NOAA

National Marine

Fisheries Service
Fishery Bulletin

¿ established 1881 ๙
Spencer F. Baird

First U.S. Commissione of Fisheries and founder of Fishery Bulletin
Abstract-We examined the stomach contents of 3 vertically migrating myctophid fish species from the eastern tropical Pacific (ETP) Ocean and used a classification tree to examine the influence of spatial, biological, and oceanographic predictor variables on diet. Myctophum nitidulum ( $n=299)$, Symbolophorus reversus ( $n=199)$, and Gonichthys tenuiculus, $(n=82)$ were collected with dip nets from surface waters, and prey taxa were quantified from bongo net tows from August through November 2006. A classification tree produced splits with longitude and sea surface salinity (SSS), thereby separating 3 geographically and oceanographically distinct regions of the ETP (offshore, nearshore, and intermediate), where diet was similar among the 3 species. Myctophids consumed, primarily, ostracods offshore $(76.4 \%$ mean percentage by number $\left.\left[M N_{i}\right]\right)$, euphausiids nearshore $(45.0 \%)$, and copepods $(66.6 \%)$ in the intermediate region. The offshore region was characterized by a greater abundance of ostracods in the zooplankton community ( $17.5 \%$ by number) and within a deep mixed-layer depth (MLD) (mean $52.6 \mathrm{~m}$, max $93.0 \mathrm{~m}$ ). SSS was low in the nearshore region $(<32.9$ psu) and the MLD was shallow. The intermediate region represented a transition zone between the oceanographic condition of the offshore and nearshore regions. Our results indicate that these 3 myctophid species share a similar regional diet that is strongly influenced by longitude, ostracod availability, SSS, and MLD.

Manuscript submitted 13 May 2015. Manuscript accepted 6 April 2016. Fish. Bull. 114:274-287 (2016). Online publication date: 28 April 2016. doi: 10.7755/FB.114.3.2

The views and opinions expressed or implied in this article are those of the author (or authors) and do not necessarily reflect the position of the National Marine Fisheries Service, NOAA.

\title{
Oceanographic influences on the diet of 3 surface-migrating myctophids in the eastern tropical Pacific Ocean
}

\author{
Joel E. Van Noord (contact author) 1,4 \\ Robert J. Olson ${ }^{2}$ \\ Jessica V. Redfern ${ }^{3}$ \\ Leanne M. Duffy² \\ Ronald S. Kaufmann ${ }^{1}$ \\ Email address for contact author: joel.vannoord@noaa.gov \\ Present address: California Wetfish Producers Association \\ P.O. Box 1951 \\ Buellton, California 93427 \\ ${ }^{1}$ Marine Science and Environmental Studies Department \\ University of San Diego \\ 5998 Alcalá Park \\ San Diego, California 92110 \\ 2 Inter-American Tropical Tuna Commission \\ 8901 La Jolla Shores Drive \\ La Jolla, California 92037 \\ ${ }^{3}$ Southwest Fisheries Science Center \\ National Marine Fisheries Service, NOAA \\ 8901 La Jolla Shores Drive \\ La Jolla, California 92037
}

The Myctophidae (lanternfishes) comprise a family of fishes whose members are both extremely abundant and distributed throughout the world's oceans (Gjosaeter and Kawaguchi, 1980; Irigoien et al., 2014). Species making up this family of fish serve roles as both important predators (Pakhomov et al., 1996) and prey (Naito et al., 2013); furthermore myctophids transfer energy from lower to higher trophic levels in food webs (Brodeur et al., 1999). Myctophids are also influential in the transfer of carbon to the deep sea because they feed in surface waters and return to the mesopelagic zone (Davison et al., 2013). The family is speciose, with as many as 250 species in 33 genera (Catul et al., 2011). In some instances, as many as 50 species can be found in close proximity, simultane- ously feeding on similar prey (Hopkins and Gartner, 1992).

Resource partitioning, broadly defined as differences in resource use among co-occurring species (Schoener, 1974), has been used to explain how diverse myctophid assemblages can co-occur without competitively excluding one another (Hopkins and Gartner, 1992). Myctophids have been shown to partition resources by size (myctophid size) (Shreeve et al., 2009; Saunders et al., 2015), migration depth, and prey type (Hopkins and Gartner, 1992; Pepin, 2013). Co-occurring myctophid species of similar size that are found in the same habitat either partition dietary resources or feed opportunistically on prey in the proportions that are available. For example, dietary resource partitioning has been de- 
scribed in myctophids in the Gulf of Mexico (Hopkins and Gartner, 1992; Hopkins and Sutton, 1998), Central Pacific (Clarke, 1980), western tropical Pacific (Van Noord 2013), Kuroshio Current (Watanabe et al., 2002), California Current (Suntsov and Brodeur, 2008), Southern Ocean (Cherel et al., 2010; Shreeve et al., 2009), and North Atlantic (Pusch et al., 2004). Conversely, generalist behavior has been described by Kinzer and Schulz (1985), who found that 7 myctophid species in the equatorial Atlantic fed opportunistically on similar calanoid copepods. Pakhomov et al. (1996) also found that 4 myctophid species in the Southern Ocean fed opportunistically on the same mesozooplankton, whereas Tyler and Pearcy (1975) found that myctophids in the California Current fed on a diverse and overlapping diet. These previous studies, although valuable, were primarily descriptive in nature, did not provide measurements of prey availability, were restricted to geographically small areas, and therefore do not provide a broad picture of myctophid feeding and the variables that govern their diet. Understanding the factors that influence the diet of myctophid fishes will provide insight into food-web dynamics and the structure of related communities. If myctophids are opportunistic feeders, for example, bottom-up forcing or environmental changes in the system would have a dynamic effect on their feeding patterns, which, in turn, would reverberate throughout the food web (Fiedler et al., 2013).

Little is known about the ecology or biology of myctophids from the eastern tropical Pacific (ETP) but in surveys of larval fish in the ETP, high densities, as well as a diversity, of myctophid species have been encountered (Ahlstrom, 1972, 1971). Studies investigating the ecological role of myctophids in this region have lumped species together as a forage base for top predators (e.g., Pitman et al. ${ }^{1}$; Maas et al. 2014) and myctophids have been documented as prey for cetaceans (Perrin et al., 1973; Scott et al., 2012), tunas, swordfish, and other large pelagic fish (Moteki et al., 2001), squids (Shchetinnikov, 1992), and seabirds (Spear et al., 2007) in the ETP. Given their importance as prey, their feeding behavior can have ramifications on how energy is transferred from lower to higher trophic levels.

The eastern tropical Pacific Ocean encompasses areas of upwelling and oligotrophy (Fiedler and Talley, 2006), and this oceanographic variability produces diverse zooplankton prey assemblages (Fernández-Álamo and Färber-Lorda, 2006). There are also diverse and abundant communities of myctophids (Ahlstrom, 1972, 1971). With the abundance of myctophids and their zooplankton prey in this region, the ETP presents an opportunity to assess feeding strategies for these fish.

Using samples collected across a productivity gradient along the North Equatorial Countercurrent

\footnotetext{
1 Pitman, R. L., L. T. Ballance, and P. C. Fiedler. 2002. Temporal patterns in distribution and habitat associations of prey fishes and squids. NOAA, Natl. Mar. Fish. Serv., Southwest Fish. Sci. Cent. Admin. Rep. LJ-02-19, 52 p. [Available at website.]
}

(NECC), we quantified the diets of 3 common surfacemigrating myctophids, and assessed the availability of prey for these species from zooplankton net hauls. Then, using a bagged (i.e., bootstrap aggregating, where classifications of randomly generated training sets are combined to improve overall model performance) classification tree (Kuhnert et al., 2012), we investigated the influence of spatial, oceanographic, and biologic (prey and predator) variables on myctophid diets. We postulate that, if dietary resources were partitioned, the diets of each species would be unique, whereas if feeding was opportunistic, myctophid diets would be related to broad-scale patterns of prey availability and oceanography.

\section{Materials and methods}

\section{Study area and data collection}

The study area is located in the ETP between the subtropical gyres of the North and South Pacific (Fiedler and Talley, 2006). The ETP contains 3 major surface currents: the North Equatorial Current (NEC), North Equatorial Countercurrent (NECC), and the South Equatorial Current (SEC [Fig. 1]). The NECC is a warm, eastward flowing current in which upwelling causes shoaling of the thermocline along an east-towest gradient near $5^{\circ} \mathrm{N}$ (Fiedler and Talley, 2006). Two eastern boundary currents at the northern (California Current) and southern (Peru Current) extent of the ETP bring cold, nutrient-rich water into the system (Fiedler and Talley, 2006). Nearshore waters associated with the Gulf of Panama have characteristically low sea-surface-salinity (SSS) values owing to high local rainfall (Amador et al., 2006).

Myctophids $(n=580)$ were collected aboard National Oceanic and Atmospheric Administration (NOAA) research vessels RV MacArthur II and RV David Starr Jordan during surveys conducted in the ETP by NOAA's Southwest Fisheries Science Center (SWFSC) from August to November 2006. Myctophids were systematically collected every night in dip nets at predetermined stations (Fig. 2) located on line transects (Fig. 3 ). A randomized subsample of myctophids captured at 32 stations was available for this study. Dipnet sampling began one hour after local sunset and lasted for 1 hour. Long-handled ( 6-m) dip nets with 1-m wide baskets and $0.5-\mathrm{cm}$ mesh size were used to catch myctophids under deck lights that illuminated approximately $10 \mathrm{~m}^{2}$ of the water surface (Coad, 1998). Researchers at the SWFSC have collected specimens using this standardized method for decades (Fiedler et al., 2013; Pitman et al. ${ }^{1}$. The dipnet method is unique in comparison with that of traditional net tows because fish are collected from the ocean environment individually and not retained in a net, thus excluding the possibility of postcapture feeding. Net avoidance associated with the bow-wave of large towed equipment is also negated with handheld dip nets. Myctophids exhibit size-related 


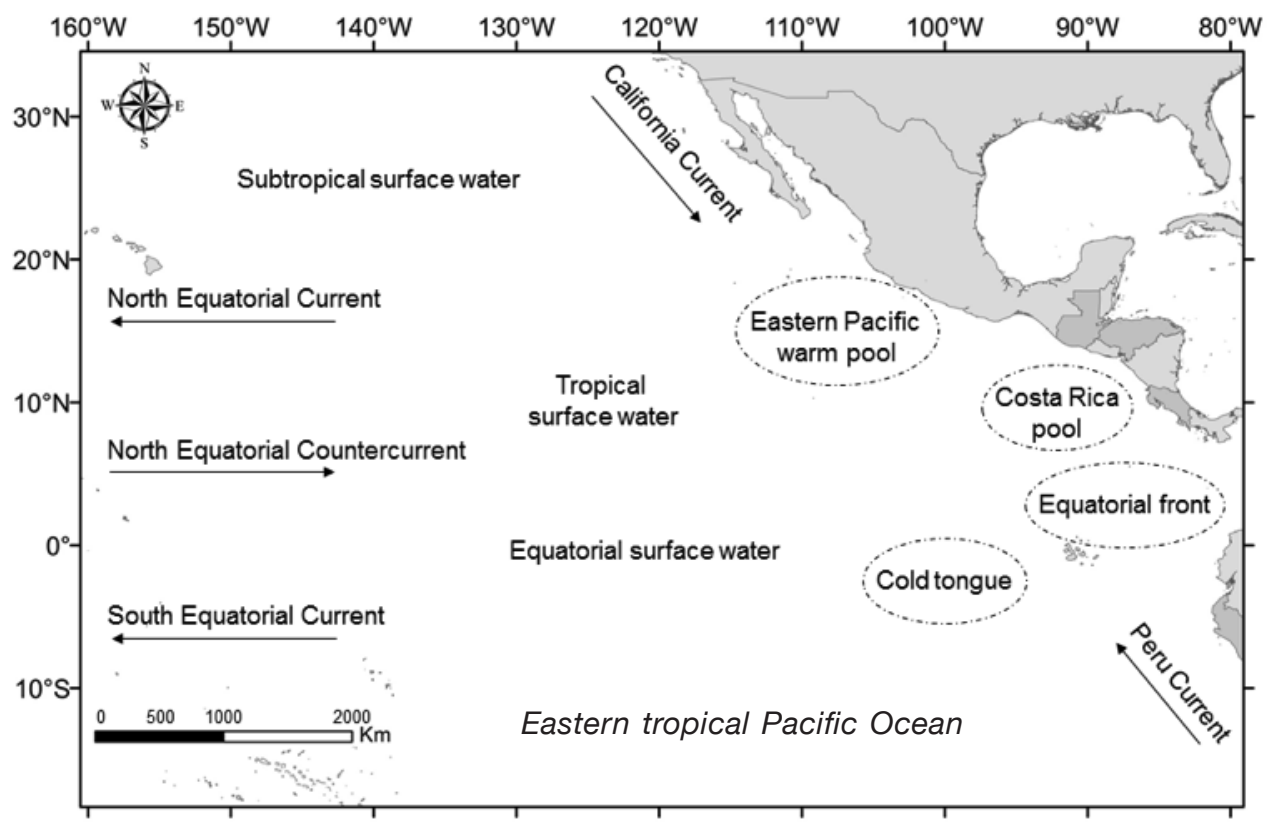

Figure 1

Major currents and oceanographic features in the eastern tropical Pacific Ocean. Arrows indicate direction of the currents. Dashed ovals signify distinct oceanographic features.

depth stratification throughout the water column, and certain, often larger, individuals remain deeper in the column (Collins et al., 2008; Saunders et al., 2015). Additionally, not all members of a surface-migrating population migrate each night, and surface-migration is likely spurred by feeding. Therefore, our samples are not representative of all size classes within this population; instead, we focused entirely on the surfacemigrating myctophids that were found in surface waters during the time of capture. Specimens were frozen whole at sea.

Zooplankton were sampled with a bongo net (0.6$\mathrm{m}$ mouth diameter, 333- $\mathrm{mm}$ mesh) towed obliquely to a depth of $200 \mathrm{~m}$ at an average ship speed of $1.75 \mathrm{kn}$. A flow meter was attached to the net to determine the amount of filtered seawater. We analyzed only net tows at the 32 stations where myctophids were collected (Fig. 2). The sampling depth of the bongo tows does not cover the entire depth range for myctophids because our study focused exclusively on the surface-migrating members of the population and we were interested in the prey that might be available to this subset of the fish community. Zooplankton also conduct diel vertical migrations from deep-water to near-surface waters and it is likely that some zooplankton had migrated from deeper than $200 \mathrm{~m}$ (Longhurst and Harrison, 1988). Depth-integrated zooplankton samples were used because myctophids feed during migration (Watanabe et al., 1999). Net tows commenced 30 min after the conclusion of dipnet sampling and the zooplankton samples were preserved at sea in $3.7 \%$ buffered formalin.

Systematic oceanographic sampling was conducted during the surveys (for details, see Fiedler and Philbrick $^{2}$ ). Sea surface temperature (SST) and SSS values were recorded with a thermosalinograph at 2-min intervals along transects (Fig 3). Surface chlorophyll-a (SCHL) concentrations were measured at approximately $55-\mathrm{km}$ intervals along transects by using a fluorometer. Mixed layer depth (MLD), i.e. the depth at the top of the thermocline, was estimated as the depth $(\mathrm{m})$ at which the temperature is $0.5^{\circ} \mathrm{C}$ less than the surface temperature. MLDs were derived from data obtained from expendable bathythermograph (XBT) and conductivity, temperature, and depth (CTD) casts. XBT casts were made at approximately $55-\mathrm{km}$ intervals along transects to a depth of $760 \mathrm{~m}$. CTD casts were undertaken at sunrise and sunset each day to a depth of $1000 \mathrm{~m}$. Using these data, Barlow et al. (2009) created smoothed (using the Kriging method) maps of SST, SSS, MLD, and SCHL data (Fig. 3) and are presented here with permission. In the classification tree model we considered, only variables coinciding with the 32 dipnet stations at which myctophids were collected.

In the laboratory, myctophids were thawed individually, identified (by using keys devised by Wisner, 1974 and Gago and Ricord, 2005), blotted, weighed to the nearest $\mathrm{mg}$, and measured to the nearest $\mathrm{mm}$ (standard length, SL). Stomachs were dissected whole from each

\footnotetext{
2 Fiedler, P. C., and V. A. Philbrick. 2002. Environmental change in the eastern tropical Pacific Ocean: observations in 1986-1990 and 1998-2000. NOAA, Natl. Mar. Fish. Serv., Southwest Fish. Sci. Cent. Admin. Rep. LJ-02-15, 16 p. [Available at website.]
} 


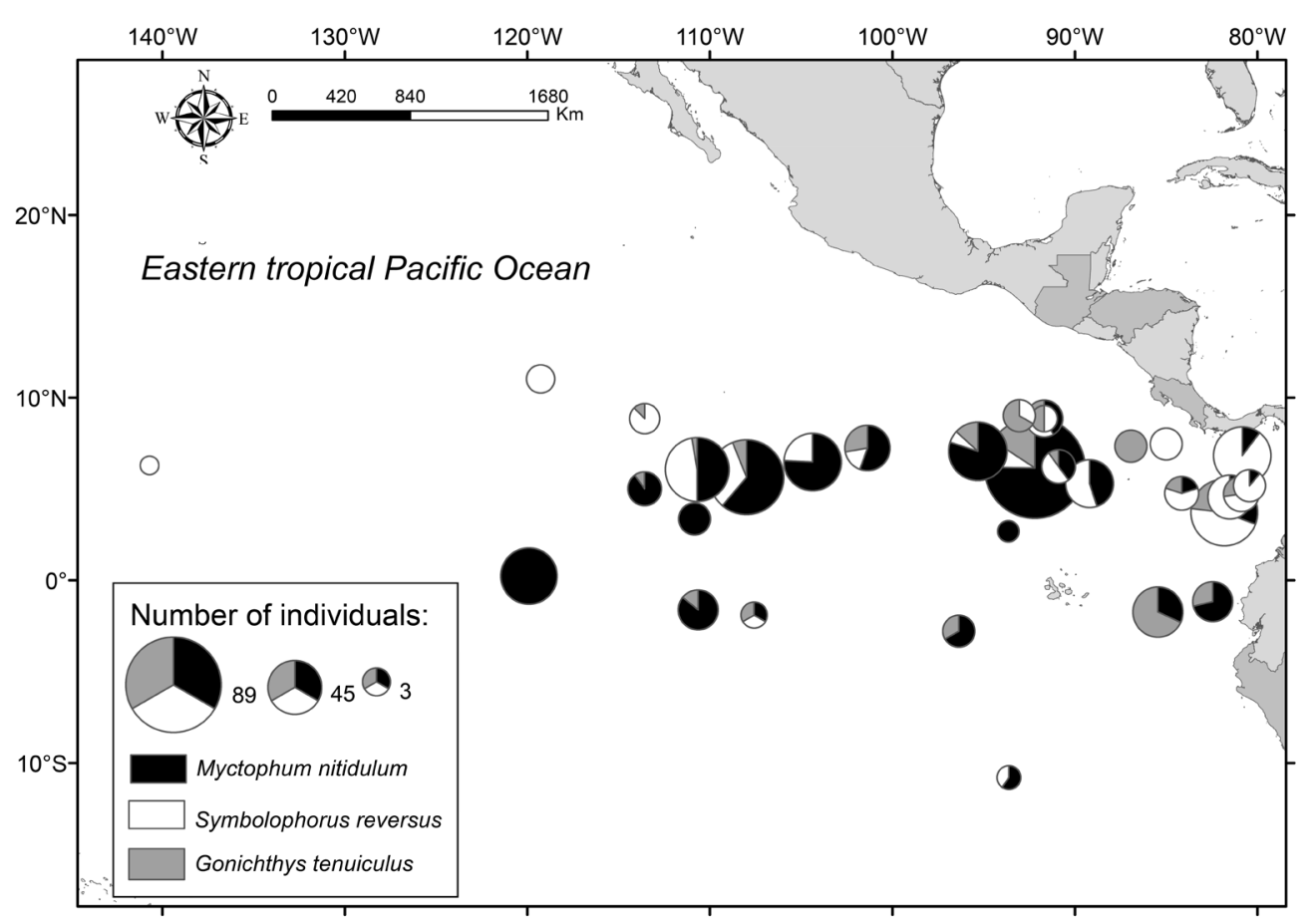

Figure 2

Species distribution of the 580 myctophid individuals of 3 myctophid species collected from the eastern tropical Pacific Ocean by dip net during 2006.

fish, weighed, fixed in 3.7\% formalin, and stored in $70 \%$ ethyl alcohol. The amount of time specimens were left either unfrozen or unpreserved was minimized to avoid degradation of stomach contents.

Displacement volumes of small zooplankton from oblique net tows were measured in the laboratory. This measurement excluded all fishes, large cephalopods, pelagic crabs, and large plankters $(>5 \mathrm{~mm})$, including Thaliacea and medusae (Ohman and Smith, 1995). Net samples were split to a one-eighth volume by using a Folsom plankton splitter, and individuals were identified under a dissecting microscope to the taxonomic level of order. Identifications were made to order level for comparison with the taxonomic resolution of most gut-content identifications. This taxonomic resolution restricted our diet analysis because we could not exclude the possibility that resource partitioning occurs at a lower taxonomic level. Zooplankton densities were standardized as numbers of individuals per $\mathrm{m}^{3}$ of water filtered at each station by using methods of Smith and Richardson (1977) and were converted to numeric percentages for comparison with gut contents.

\section{Diet composition}

We identified stomach contents to the lowest possible taxon and enumerated and weighed contents by taxonomic group. Pieces of plastic found in stomachs were not included in the analysis of the natural diet. Stomachs void of all material, including unidentifiable substance, were classified as empty.
We calculated mean percentage by number $\left(M N_{i}\right)$ by using the following equation:

$$
N_{i}=\frac{1}{P} \sum_{j=1}^{P}\left(\frac{N_{i j}}{\sum_{i=1}^{Q} N_{i j}}\right) \times 100,
$$

where $N_{i j}=$ the count of prey type $i$ in fish $j$;

$Q=$ the number of prey types in the stomach of fish $j$; and

$P=$ the number of fish with food in their stomachs in any particular sampling stratum (Chipps and Garvey, 2007).

We calculated mean percentage by weight $\left(M W_{i}\right)$ similarly, substituting prey weights $(W)$ for counts $(N)$. Percent occurrence $\left(O_{i}\right)$ was calculated as the number of fish containing a specific prey item $i$, divided by the total number of fish sampled, including those myctophids with empty stomachs, and multiplied by 100 . We focused our analysis on the numeric predation data for comparison with the numeric zooplankton prey data.

\section{Classification tree analysis}

We applied Classification and Regression Tree (CART) analysis to the myctophid diet data, using the modified approach of Kuhnert et al. (2012 [see also Olson et al., 2014]). CART is a nonparametric modeling approach described by Breiman et al. (1984). Diet data are partitioned by forming successive splits on predictor variables in order to minimize an error criterion, in this case the Gini index, which represents a mea- 


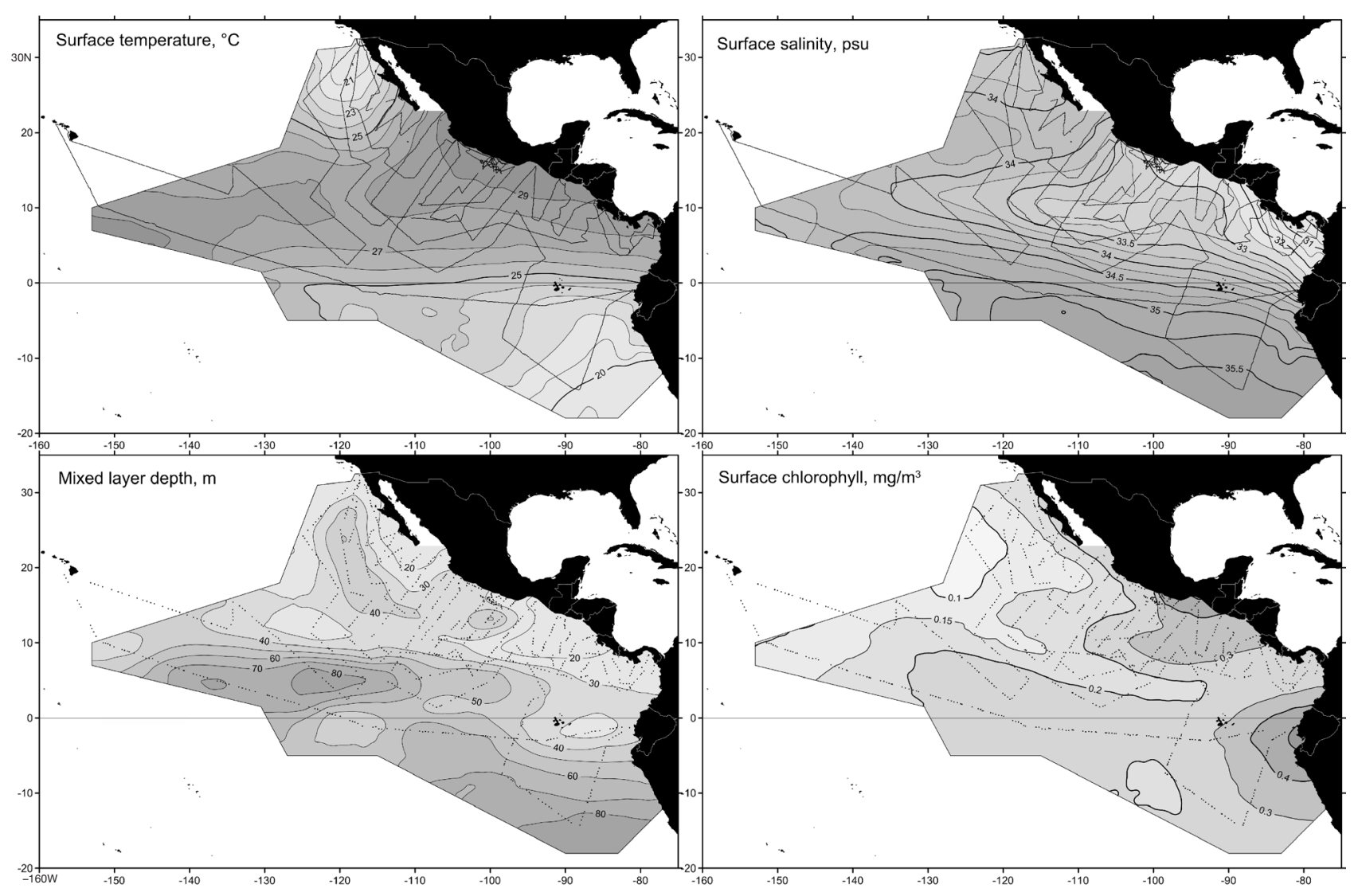

Figure 3

Oceanographic maps smoothed (with the Kriging method) and created by Barlow et al. (2009) and used with permission, displaying (clockwise from top left) surface temperature, surface salinity, surface chlorophyll, and mixed layer depth values in the eastern tropical Pacific (shaded region). Ship track-lines are shown with solid or dashed lines. Solid lines indicate sampling was continuous. Dashed lined indicated sampling was conducted at 55-km intervals. Numbers along isopleths indicate values for the variable represented in each map. Only variables coinciding with the 32 dipnet stations were used in the classification and regression tree (CART) analysis.

sure of diet diversity ranging from 0 (no diet diversity) to 1 (high diet diversity) among predicted prey categories. A large tree is produced and 10-fold crossvalidation is used to prune the tree to within one standard error of the tree yielding the minimum error (i.e., the "1 SE" rule [Breiman et al., 1984; Kuhnert et al., 2012]). Predictions are made by partitioning a new observation down the tree until it resides in a terminal node. The prey group with the greatest numeric proportion among a suite of prey in the diet is displayed at each terminal node. The vector of prey proportions, in numbers of prey eaten by an individual predator is represented as a univariate categorical response variable of prey type (class), with observation (case) weights equal to the proportion of the prey type eaten by the predator. Fish with empty stomachs were omitted from this analysis because we were interested in how predictor variables influenced prey type. Rankings of variable importance are computed to identify which predictor variables are most important in the model. In addition, Kuhnert et al. (2012) implemented a spatial bootstrapping technique to account for spa- tial dependence in the data and to assess uncertainty in the predicted diet composition at each node in the classification tree. The classification was implemented in $\mathrm{R}$ software, vers. 3.1.1 ( $\mathrm{R}$ Core Team, 2014) with the 'rpart' package (Therneau et al., 2013); further details can be found in Kuhnert et al. (2012).

We used CART analysis to explore the relationship among 12 dependent spatial, oceanographic, and biological predictor variables (Table 1 ) and the response variable, diet composition. Spatial predictors included latitude and longitude, oceanographic predictors consisted of MLD, SSS, SST, and SCHL concentration, and biological predictors contained information on the zooplankton prey community by using data from the net samples and the myctophid predators. Data representing the zooplankton community (potential prey) included ostracod, copepod, and euphausiid numeric composition and zooplankton displacement volume in the net samples (Table 2). Standard fish length was used to assess the effects of ontogenetic diet. We used species as a predictor variable to assess resource-partitioning among species. 


\section{Table 1}

Geographic, oceanographic, and biologic predictor variables used in the analysis to determine the diet of 3 myctophids in the eastern tropical Pacific Ocean. Fish were collected from August through November 2006.

\begin{tabular}{llc}
\hline Predictor variable & Type of variable & Mean (Min.-Max) \\
\hline $\begin{array}{l}\text { Longitude } \\
\text { Latitude }\end{array}$ & Spatial & $140.7^{\circ} \mathrm{W}$ to $80.4^{\circ} \mathrm{W}$ \\
Myctophid species & Spatial & $11.0^{\circ} \mathrm{S}$ to $10.8^{\circ} \mathrm{N}$ \\
& Biological & Myctophum nitidulum, Symbolophorus \\
Myctophid standard length & reversus, Gonichthys tenuiculus \\
Ostracod zooplankton (ZP) composition & Biological & $50.4 \mathrm{~mm}(25-80)$ \\
Copepod ZP composition & Biological & $10.9 \%(1.2-37.0)$ \\
Euphausiid ZP composition & Biological & $72.2 \%(45.0-87.3)$ \\
Zooplankton volume & Biological & $4.4 \%(1.8-20.7)$ \\
Mixed layer depth (MLD) & Oceanographic & $97.5 \mathrm{~mL}(1,000) / \mathrm{m}^{3}(44-241)$ \\
Sea surface salinity (SSS) & Oceanographic & $38.1 \mathrm{~m}(6-93)$ \\
Sea surface temperature (SST) & Oceanographic & $33.25 \mathrm{psu}(31.21-35.58)$ \\
Surface chlorophyll (SCHL) & Oceanographic & $21.2^{\circ} \mathrm{C}(21.9-29.2)$ \\
& & $0.184 \mathrm{mg} / \mathrm{m}^{3}(0.002-0.382)$
\end{tabular}

We categorized the myctophid diet into 17 prey groups in the CART analysis (14 are shown in Table $3)$. These groups ranged in taxonomic level from family (e.g., Euchaetidae) to phylum (e.g., Mollusca) because the taxonomic resolution of prey identifications varied and because some rare prey were combined into broader taxa along with unidentifiable specimens. For the CART analysis, all mollusks were grouped together, as were all euphausiids, and all cyclopoid copepods. Rare calanoid copepods, defined as types contributing less than $1 \% M N_{i}$ to all 3 myctophid species were grouped as "other copepods." Rare amphipods, defined as types contributing less than $0.3 \%$ in $M N_{i}$ were grouped as "other amphipods." The "other" copepod and amphipod groups contained a majority of unidentifiable specimens. Decapods $(0.5 \%$ combined mean $M N_{i}$ ), fish eggs $(0.3 \%)$, and the one cephalopod $(<0.1 \%)$ were not included in the analysis because of their scarcity.

\section{Results}

\section{Oceanographic variables}

The MLD, SSS, SST, and SCHL concentrations each showed distinct geographic patterns within the study area. MLD deepened from east to west along the NECC, between the equator and $10^{\circ} \mathrm{N}$ (Fig. 3). At its shallowest, MLD (mean $38.1 \pm 20.5 \mathrm{~m}$ standard deviation [SD], averaged over the 32 dipnet stations) was $6 \mathrm{~m}$ deep nearshore $\left(8^{\circ} \mathrm{N}, 91^{\circ} \mathrm{W}\right)$ and reached $93 \mathrm{~m}$ at the station farthest offshore $\left(6^{\circ} \mathrm{N}, 140^{\circ} \mathrm{W}\right)$. SSS (mean $33.3 \pm 1.20$ practical salinity units [psu]) was lowest (31.21 psu) near the coast of Central America, and became more saline farther offshore and south of the equator (max. of $35.5 \mathrm{psu}$ ). SST (mean $21.2 \pm 1.90^{\circ} \mathrm{C}$ ) showed little variation along the NECC, where the majority of sta- tions occurred. Surface chlorophyll- $a$ values (mean 0.20 $\pm 0.08 \mathrm{mg} / \mathrm{m}^{3}$ ) were greatest along the coast of southern Mexico and Ecuador and decreased offshore (Fig. 3).

\section{Myctophid size-composition}

The individuals collected at the surface nightly by dip net differed morphologically (Fig. 4). Symbolophorus reversus ( $n=199 ; 172$ with identifiable prey remains) was the largest of the 3 species in length (mean=55.9 \pm 8.8 $\mathrm{mm} \mathrm{SD})$ and weight $(2.66 \pm 1.27 \mathrm{~g}$ SD). Myctophum nitidulum ( $n=299 ; 275$ with identifiable prey remains) was intermediate in length $(47.9 \pm 6.6 \mathrm{~mm})$ and weight $(1.82$ $\pm 0.80 \mathrm{~g}$ ). Gonichthys tenuiculus ( $n=82 ; 26$ with identifiable prey remains), was the smallest species in length $(37.8 \pm 4.3 \mathrm{~mm})$ and weight $(0.54 \pm 0.21 \mathrm{~g}$ [Fig. 4] $)$.

\section{Diet composition}

Prey composition data for each of the 3 species are summarized by the 3 diet indices, $M N_{i}, M W_{i}$, and $O_{i}$ in Table 2. We focused our data analysis on the numeric diet index for consistency with the numeric data on prey availability. We included the weight and occurrence indices in Table 2, however, so that our data are comparable with other published data.

\section{Zooplankton community}

Seventeen unique taxonomic groups of zooplankton were identified and enumerated ( $n=178,090$ individuals) in the net tows. Copepods were by far the most abundant group, representing as much as $87.3 \%$ of the community sampled and never less than $45.0 \%$ at any station (Table 3, Fig. 5). Ostracods were the second most abundant group overall $(8.65 \pm 10.1 \%)$. Euphausiids and amphipods each contributed $<5 \%$ of the sampled community. 


\section{Table 2}

Percentages of the prey composition for 3 myctophids collected at 32 stations in the eastern tropical Pacific Ocean. Samples of zooplankton prey were taken with an oblique haul of a bongo net. Offshore, intermediate, and nearshore regions were identified by a classification tree analysis (Fig. 7). Standard deviations are shown in parentheses.

\begin{tabular}{|c|c|c|c|c|c|c|c|}
\hline Latitude & Longitude & $\begin{array}{c}\text { Amphipods } \\
(\%)\end{array}$ & $\begin{array}{c}\text { Copepods } \\
(\%)\end{array}$ & $\begin{array}{c}\text { Euphausiids } \\
(\%)\end{array}$ & $\begin{array}{c}\text { Euphausiids } \\
(\%)\end{array}$ & $\begin{array}{c}\text { Other } \\
\text { prey } \\
(\%)\end{array}$ & $\begin{array}{c}\text { Nonprey } \\
\text { items } \\
(\%)\end{array}$ \\
\hline $6.30^{\circ} \mathrm{N}$ & $140.72^{\circ} \mathrm{W}$ & 0.55 & 72.9 & 2.37 & 12.1 & 3.29 & 8.78 \\
\hline $0.23^{\circ} \mathrm{N}$ & $119.92^{\circ} \mathrm{W}$ & 1.52 & 76.6 & 3.07 & 3.09 & 2.79 & 13.0 \\
\hline $11.03^{\circ} \mathrm{N}$ & $119.28^{\circ} \mathrm{W}$ & 1.43 & 82.8 & 2.92 & 1.80 & 4.06 & 7.00 \\
\hline $5.02^{\circ} \mathrm{N}$ & $113.58^{\circ} \mathrm{W}$ & 1.62 & 61.0 & 2.58 & 22.3 & 2.38 & 10.1 \\
\hline $8.25^{\circ} \mathrm{N}$ & $113.17^{\circ} \mathrm{W}$ & 1.38 & 45.0 & 5.98 & 33.6 & 2.66 & 11.3 \\
\hline $3.37^{\circ} \mathrm{N}$ & $110.85^{\circ} \mathrm{W}$ & 2.17 & 67.5 & 2.35 & 9.74 & 4.00 & 14.3 \\
\hline $6.07^{\circ} \mathrm{N}$ & $110.70^{\circ} \mathrm{W}$ & 2.05 & 45.2 & 4.61 & 37.0 & 5.17 & 6.04 \\
\hline $1.62^{\circ} \mathrm{S}$ & $110.65^{\circ} \mathrm{W}$ & 1.07 & 69.8 & 4.94 & 5.16 & 1.38 & 17.6 \\
\hline $5.65^{\circ} \mathrm{N}$ & $108.00^{\circ} \mathrm{W}$ & 1.45 & 61.1 & 5.54 & 19.7 & 6.29 & 5.84 \\
\hline $1.90^{\circ} \mathrm{S}$ & $107.58^{\circ} \mathrm{W}$ & 1.73 & 76.7 & 4.36 & 2.78 & 0.36 & 14.1 \\
\hline $6.48^{\circ} \mathrm{N}$ & $104.38^{\circ} \mathrm{W}$ & 1.02 & 49.3 & 3.12 & 32.9 & 2.00 & 11.6 \\
\hline $6.33^{\circ} \mathrm{N}$ & $101.73^{\circ} \mathrm{W}$ & 1.15 & 70.5 & 3.89 & 15.4 & 1.78 & 7.30 \\
\hline $7.25^{\circ} \mathrm{N}$ & $101.37^{\circ} \mathrm{W}$ & 1.35 & 65.0 & 5.13 & 17.6 & 2.19 & 8.68 \\
\hline $2.78^{\circ} \mathrm{S}$ & $96.37^{\circ} \mathrm{W}$ & 1.24 & 78.4 & 3.87 & 3.11 & 1.67 & 11.7 \\
\hline $7.07^{\circ} \mathrm{N}$ & $95.32^{\circ} \mathrm{W}$ & 0.82 & 82.5 & 2.35 & 1.53 & 3.55 & 9.20 \\
\hline $2.68^{\circ} \mathrm{N}$ & $93.65^{\circ} \mathrm{W}$ & 0.82 & 81.8 & 2.50 & 5.18 & 4.36 & 5.29 \\
\hline $10.8^{\circ} \mathrm{S}$ & $93.62^{\circ} \mathrm{W}$ & 0.76 & 61.7 & 20.7 & 1.48 & 1.58 & 13.8 \\
\hline $9.02^{\circ} \mathrm{N}$ & $93.05^{\circ} \mathrm{W}$ & 2.56 & 82.1 & 3.63 & 2.00 & 7.57 & 2.14 \\
\hline $6.15^{\circ} \mathrm{N}$ & $92.20^{\circ} \mathrm{W}$ & 1.91 & 79.9 & 4.37 & 3.21 & 3.01 & 7.64 \\
\hline $8.37^{\circ} \mathrm{N}$ & $91.68^{\circ} \mathrm{W}$ & 1.76 & 79.8 & 4.01 & 1.66 & 2.60 & 10.2 \\
\hline $6.23^{\circ} \mathrm{N}$ & $90.90^{\circ} \mathrm{W}$ & 2.15 & 76.2 & 3.07 & 3.73 & 2.86 & 12.0 \\
\hline $5.30^{\circ} \mathrm{N}$ & $89.20^{\circ} \mathrm{W}$ & 1.57 & 75.8 & 4.20 & 3.06 & 1.14 & 14.3 \\
\hline $7.35^{\circ} \mathrm{N}$ & $86.93^{\circ} \mathrm{W}$ & 1.15 & 72.7 & 5.51 & 5.49 & 1.09 & 14.1 \\
\hline $1.73^{\circ} \mathrm{S}$ & $85.45^{\circ} \mathrm{W}$ & 1.72 & 80.7 & 3.29 & 1.21 & 4.98 & 8.04 \\
\hline $7.47^{\circ} \mathrm{N}$ & $85.00^{\circ} \mathrm{W}$ & 1.15 & 81.2 & 3.74 & 1.21 & 1.77 & 10.9 \\
\hline $4.77^{\circ} \mathrm{N}$ & $84.15^{\circ} \mathrm{W}$ & 1.22 & 77.4 & 4.41 & 3.54 & 0.83 & 12.6 \\
\hline $1.17^{\circ} \mathrm{S}$ & $82.45^{\circ} \mathrm{W}$ & 0.48 & 87.3 & 1.78 & 1.45 & 3.22 & 5.73 \\
\hline $3.72^{\circ} \mathrm{N}$ & $81.82^{\circ} \mathrm{W}$ & 1.08 & 77.0 & 3.73 & 4.58 & 1.72 & 11.9 \\
\hline $4.57^{\circ} \mathrm{N}$ & $81.52^{\circ} \mathrm{W}$ & 1.07 & 76.7 & 4.07 & 2.76 & 5.76 & 9.64 \\
\hline $4.73^{\circ} \mathrm{N}$ & $80.88^{\circ} \mathrm{W}$ & 1.34 & 69.6 & 5.29 & 6.40 & 2.60 & 14.8 \\
\hline $6.83^{\circ} \mathrm{N}$ & $80.83^{\circ} \mathrm{W}$ & 1.23 & 75.5 & 4.21 & 5.23 & 1.14 & 12.7 \\
\hline $5.18^{\circ} \mathrm{N}$ & $80.43^{\circ} \mathrm{W}$ & 0.61 & 70.5 & 5.44 & 6.62 & 3.83 & 12.9 \\
\hline \multicolumn{8}{|l|}{ Region } \\
\hline Offshore & & 1.40 & 63.9 & 3.90 & 17.5 & 3.20 & 10.1 \\
\hline Intermediate & & 1.50 & 80.5 & 3.30 & 2.60 & 3.50 & 8.60 \\
\hline Nearshore & & 1.11 & 75.1 & 4.55 & 4.48 & 2.34 & 12.5 \\
\hline \multirow{2}{*}{ Mean } & & 1.35 & 72.2 & 4.41 & 8.65 & 2.93 & 10.5 \\
\hline & & $( \pm 0.49)$ & $( \pm 10.7)$ & $( \pm 3.16)$ & $( \pm 10.1)$ & $( \pm 1.69)$ & $( \pm 3.46)$ \\
\hline
\end{tabular}

\section{Classification tree analysis}

The classification tree analysis produced a tree with 2 splits and 3 terminal nodes (Fig. 6A) and yielded a cross-validated error rate of 0.73 (standard error $[\mathrm{SE}]=0.04$, coefficient of multiple determination $\left[R^{2}\right]=\sim 27 \%$ ). The rankings of variable importance (Fig. $6 \mathrm{~B})$ indicated that longitude was the most important variable (i.e., rank=1.00) for predicting the diet composition of these myctophids. The ostracod numeric composition of the zooplankton (rank=0.74), the cope- pod composition of the zooplankton (rank=0.61), MLD (rank=0.61), and SSS (rank=0.50) were the next most important. Myctophid species (rank=0.08) was a less important predictor variable in the classification tree given our collection of surface-migrating fishes and at the taxonomic level possible in this study. Latitude, myctophid length, SST, SCHL, zooplankton volume, and euphausiid composition in the zooplankton net samples yielded an importance rank of zero.

The initial split in the tree provided the greatest reduction in deviance over the entire data set and par- 


\section{Table 3}

Summary of stomach contents (including pieces of plastic) of 3 myctophid species collected in the eastern tropical Pacific Ocean during 2006. Diet indices include mean percentages by number $\left(M N_{i}\right)$, weight $\left(M W_{i}\right)$, and percent occurrence $\left(O_{i}\right)$. Fourteen of the 17 prey groups used in the classification tree analysis are designated with an "X." Unidentifiable and rare individuals (generally contributing $<1 \% M N_{i}$ to the diet) within the broader taxonomic group are not displayed. $\mathrm{CART}=$ classification and regression tree analysis. Bold font represents total values for a subclass and order of prey.

\begin{tabular}{|c|c|c|c|c|c|c|c|c|c|c|}
\hline & \multirow{2}{*}{$\begin{array}{l}\text { Used (X) } \\
\text { in CART }\end{array}$} & \multicolumn{3}{|c|}{$\begin{array}{l}\text { Myctophum } \\
\text { nitidulum }\end{array}$} & \multicolumn{3}{|c|}{$\begin{array}{c}\text { Symbolophorus } \\
\text { reversus }\end{array}$} & \multicolumn{3}{|c|}{$\begin{array}{l}\text { Gonichthys } \\
\text { tenuiculus }\end{array}$} \\
\hline & & $M N_{i}$ & $M W_{i}$ & $O_{i}$ & $M N_{i}$ & $M W_{i}$ & $O_{i}$ & $M N_{i}$ & $M W_{i}$ & $O_{i}$ \\
\hline Copepoda & & 42.7 & 39.1 & 69.6 & 32.5 & 28.3 & 50.3 & 18.6 & 17.6 & 7.3 \\
\hline Calanoida & & 36.4 & 37.5 & 62.5 & 27.1 & 23.3 & 45.2 & 18.6 & 17.6 & 7.3 \\
\hline Calanidae & $\mathrm{X}$ & 1.01 & 1.44 & 10.7 & 0.29 & 0.15 & 1.51 & 3.85 & 4 & 1.22 \\
\hline Candaciidae-Candacia spp. & $\mathrm{X}$ & 1.47 & 1.84 & 14.4 & 5.53 & 5.04 & 16.1 & 0 & 0 & 0 \\
\hline Eucalanidae & $\mathrm{X}$ & 1.79 & 2.51 & 14.4 & 0.12 & 0.27 & 1 & 0 & 0 & 0 \\
\hline Euchaetidae & $\mathrm{X}$ & 7.33 & 10.2 & 32.1 & 6.94 & 15 & 15.1 & 3.85 & 4 & 1.22 \\
\hline Pontellidae & $\mathrm{X}$ & 0.5 & 0.64 & 6.69 & 0 & 0 & 0 & 3.01 & 2.44 & 2.44 \\
\hline Cyclopoida & & 6.26 & 2.89 & 35.5 & 5.33 & 4.99 & 14.1 & 0.55 & 0 & 1.22 \\
\hline Corycaeidae-Corycaeus spp. & $\mathrm{X}$ & 1.43 & 0.56 & 12.7 & 0.37 & 0 & 1.51 & 0 & 0 & 0 \\
\hline Oncaeidae-Onceaea spp. & $\mathrm{X}$ & 4.8 & 2.33 & 27.4 & 4.73 & 1.81 & 13.6 & 0 & 0 & 0 \\
\hline Ostracoda & & 41.5 & 39.1 & 45.5 & 24.4 & 18.1 & 26.1 & 34.6 & 36 & 11 \\
\hline Cypridinidae-Cypridina americana & $\mathrm{X}$ & 41.3 & 38.8 & 45.1 & 24.4 & 18.1 & 26.1 & 34.6 & 36 & 11 \\
\hline Euphausiacea & $\mathrm{X}$ & 3.29 & 3.42 & 13 & 29.6 & 34.5 & 47.2 & 19.4 & 16.4 & 7.32 \\
\hline Euphausia diomedeae & & 0 & & 0 & 2.86 & & 6.53 & 0 & & 0 \\
\hline E. mutica & & 0.08 & & 0.67 & 4.15 & & 10.1 & 0 & & 0 \\
\hline E. tenera & & 0.16 & & 2.01 & 2.34 & & 8.04 & 0 & & 0 \\
\hline Euphausia spp. & & 2.18 & & 10 & 19.6 & & 7 & 19.4 & & 7.32 \\
\hline Amphipoda & & 8.38 & 12.1 & 35.8 & $\mathbf{7 . 5 8}$ & 9.61 & 20.1 & 27.3 & $\mathbf{3 0}$ & 9.76 \\
\hline Hyperiidae & $\mathrm{X}$ & 3.86 & 5.42 & 20.1 & 4.6 & 5.32 & 15.1 & 9.34 & 11.5 & 3.66 \\
\hline Pronoidae & $\mathrm{X}$ & 1.23 & 2.54 & 8.36 & 0.24 & 0.37 & 3.02 & 4.81 & 6 & 2.44 \\
\hline Platyscellidae & $\mathrm{X}$ & 0.32 & 1.11 & 3.34 & 0.3 & 1.09 & 3.02 & 0 & 0 & 0 \\
\hline Mollusca & $\mathrm{X}$ & 2.98 & 4.35 & 14.7 & 2.48 & 3.59 & 8.54 & $\mathbf{0}$ & $\mathbf{0}$ & $\mathbf{0}$ \\
\hline Atlantidae & & 0.12 & 0.32 & 2.01 & 0.39 & 0.75 & 2.51 & 0 & 0 & 0 \\
\hline Janthinidae & & 1.44 & 1.99 & 8.01 & 1.42 & 1.8 & 2.51 & 0 & 0 & 0 \\
\hline Limacinidae_Limacina spp. & & 0.4 & 0.48 & 1 & 0 & 0 & 0 & 0 & 0 & 0 \\
\hline Cavoliniidae-Diacria schmidti & & 0.03 & 0.16 & 0.67 & 0.03 & 0.16 & 0.5 & 0 & 0 & 0 \\
\hline Unidentified Mollusk & & 0.98 & 1.35 & 5.69 & 0.64 & 0.88 & 3.02 & 0 & 0 & 0 \\
\hline Larval fish & $\mathrm{X}$ & 0.12 & 0.19 & 0.33 & 2.09 & 3.63 & 7.04 & $\mathbf{0}$ & $\mathbf{0}$ & $\mathbf{0}$ \\
\hline Decapoda & & 0.33 & 0.47 & 3.01 & 1.09 & 1.86 & 3.02 & $\mathbf{0}$ & $\mathbf{0}$ & 0 \\
\hline Fish egg & & 0.78 & 0.16 & $\mathbf{3 . 3 4}$ & 0.08 & 1.21 & 0.5 & $\mathbf{0}$ & $\mathbf{0}$ & $\mathbf{0}$ \\
\hline Cephalopoda & & o & o & o & 0.19 & 0.3 & 0.5 & $\mathbf{0}$ & $\mathbf{0}$ & o \\
\hline Plastic & & & & 2.01 & & & o & & & 1.22 \\
\hline Total stomachs & & 299 & & & 199 & & & 82 & & \\
\hline
\end{tabular}

titioned the diet composition for 271 myctophids sampled east of $100^{\circ} \mathrm{W}$, on the left side of the tree (node 2 ), from the diet composition of 196 myctophids sampled west of $100^{\circ} \mathrm{W}$, on the right side of the tree (i.e., terminal node 3) (Figs. 6 and 7). Ostracod composition in the zooplankton was a strong competitor-split variable, i.e, ostracod composition in the zooplankton preformed only $2 \%$ worse than longitude at this partition (node 2). The diet composition of the myctophids east of $100^{\circ} \mathrm{W}$ was variable, and the tree further separated 169 samples caught in waters of relatively high salinity, SSS $\geq 32.86$, east of $100^{\circ} \mathrm{W}$ (terminal node 4) from 102 samples caught in waters of relatively low salinity, SSS $<32.86$, east of $100^{\circ} \mathrm{W}$ and near the Panama Bight (terminal node 5 [Figs. 6 and 7]).
Terminal node 3 All myctophids in the offshore region (Fig. 7) consumed large proportions of the ostracod Cypridina americana (mean $M N_{i}: 76.4 \%$ ) and small numbers of several other prey (Fig. 7). The diet diversity (0.22) of the myctophids in this region (terminal node 3) was lowest among all terminal nodes. Ostracods were the most numerically abundant and the MLD was the deepest at the 13 stations within the offshore region.

Terminal node 4 The 169 myctophids residing in terminal node 4 consumed large proportions of copepods (mean $M N_{i}: 66.6 \%$ ) that were identifiable as euchaetids. These myctophids were captured at 9 stations at intermediate distances from the coast, between $100^{\circ} \mathrm{W}$ 


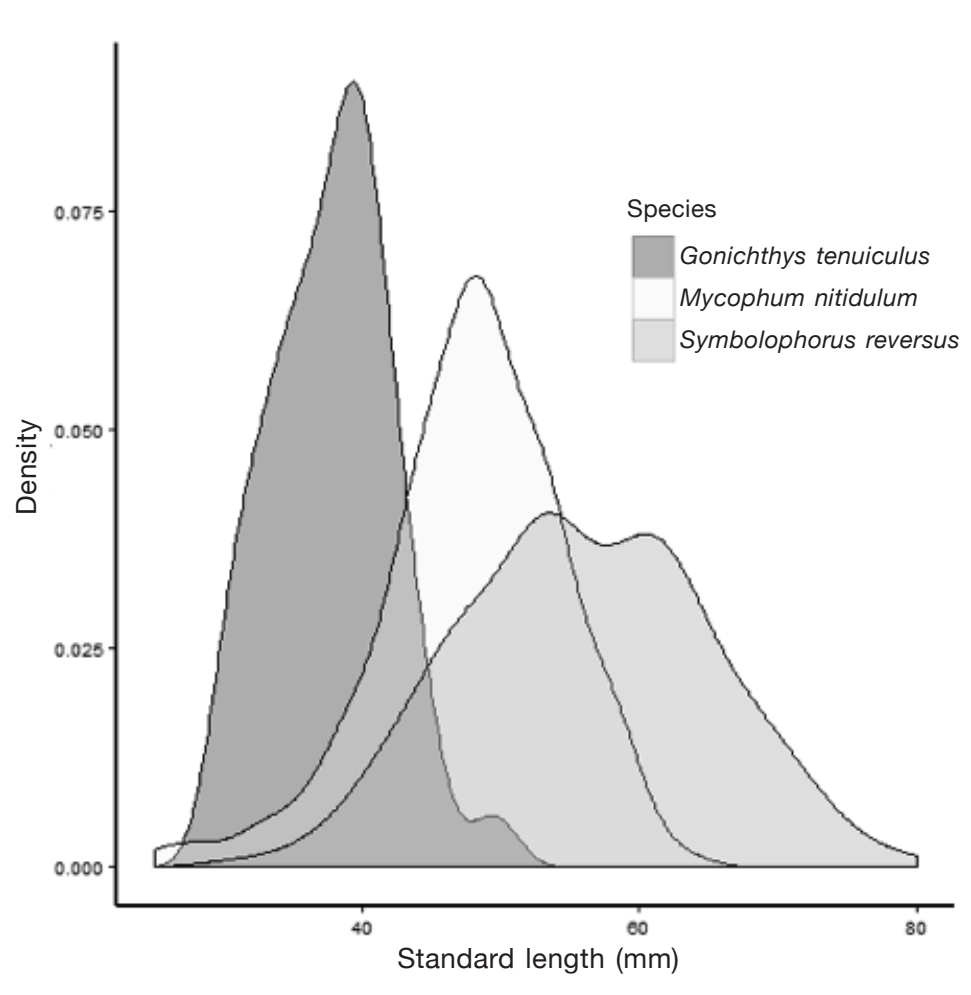

Figure 4

Length-frequency plot for the 3 myctophid species captured from surface waters in the eastern tropical Pacific during 2006. Sizes reflect our unique specimen collection and are not representative of the entire population because only surface-migrants were targeted. eggs, one squid paralarva, and one terrestrial insect (Table 2).

Interspecific dietary differences were apparent and might have been more definitive if the prey were identified at a lower taxonomic level. Previous research has, for example, indicated that these species are selective feeders (Van Noord et al., 2013b). We further assessed these previous findings by including a broad suite of predictor variables and found that "myctophid species" ranked relatively low in explaining diet patterns across the ETP. Myctophum nitidulum fed on copepods $(42.7 \%)$ and ostracods $(41.5 \%$ [Table 2]). Symbolophorus reversus fed primarily on copepods (32.5\%), euphausiids $(29.6 \%)$, and ostracods (24.4\%). Gonichthys tenuiculus took prey from only 4 groups, primarily ostracods $(34.6 \%)$ and amphipods (27.3\% [Table 2]).

Distribution patterns differed somewhat among the 3 myctophids. Figure 2 displays spatial trends in abundance; greater numbers of $S$. reversus and $G$. tenuiculus occurred in the nearshore and intermediate areas, respectively. The individuals in this study, however, represent subsamples of the captured myctophids, and no quantitative distribution analysis was possible. However, representatives of each species were captured across the entire sampling region, resulting in adequate distributional overlap, but the tree and $89^{\circ} \mathrm{W}$, and nearshore off Ecuador (Fig. 7). Net samples revealed copepods were the most numerically abundant zooplankton (80.5\%, compared with 63.9 and $75.1 \%$ in the offshore and nearshore regions) in this region (Table 3 ). This intermediate region was characterized by moderate values of MLD, SSS, and SCHL (Fig. 3), and it appears to represent a transition zone between the offshore and nearshore regions.

Terminal node 5 The myctophids sampled at 8 nearshore stations near the Panama Bight, east of $87^{\circ} \mathrm{W}$ and north of $3^{\circ} \mathrm{N}$, (Fig. 7) consumed primarily euphausiids (mean $M N_{i}: 45.0 \%$ ). SSS in this region was low (<32.86 [Fig. 3]), the MLD was shallow (mean MLD: $22.9 \mathrm{~m})$, and SCHL concentrations $\left(0.22 \mathrm{mg} / \mathrm{m}^{3}\right)$ were greater than those at stations identified within the other regions.

\section{Interspecific patterns}

Collectively, the predominant prey of these myctophids came from 4 groups, copepods $\left(M N_{i}=37.7 \%\right)$, ostracods (34.9\%), euphausiids (13.7\%), and amphipods $(9.1 \%)$, which accounted for more than $95 \%$ of the diet, by number. The remaining 5\% comprised mollusks (pteropods and heteropods, $2.6 \%$ ), larval fishes, decapods, fish analysis did not indicate that myctophid species are an important variable in characterizing the diet of the fishes in this study.

\section{Discussion}

We used a classification tree to examine the influence of spatial, biological, and oceanographic predictors on diet and found that feeding by the collection of surfacemigrating myctophids in this study was controlled by prey distribution and resource-driven processes, such as mixed-layer depth, productivity, and sea surface salinity, whereas the influence of dietary resource partitioning was a minor controlling factor. These myctophids shared a similar diet, consisting primarily of copepods, ostracods, euphausiids, and amphipods. Diet of all 3 species changed geographically, and with oceanographic conditions and zooplankton prey composition. Myctophids consumed ostracods offshore where the mixed layer depth was deep and ostracods were more abundant in the prey community, euphausiids nearshore where the MLD was shallow, and copepods at intermediate stations between those stations where they were most abundant. Understanding myctophid feeding behavior can provide insight into how these 


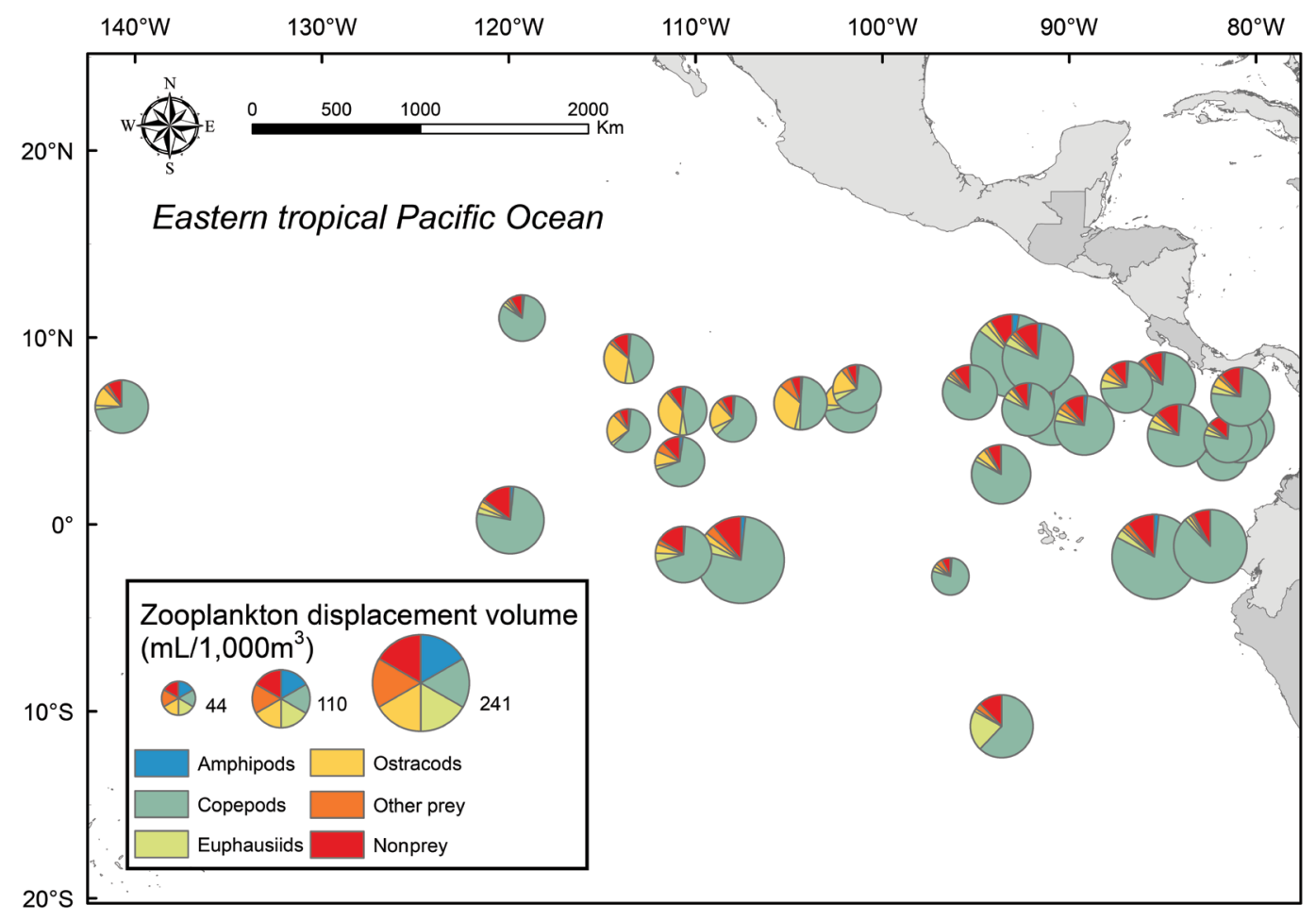

Figure 5

Distribution of the prey community sampled with an oblique bongo net in the eastern tropical Pacific Ocean. Each color represents a zooplankton prey species, other prey species, or non-prey species. Circle size reflects zooplankton displacement volume. The numbers 44, 110, and 241 indicate zooplankton displacement volume $\left(\mathrm{mL} / 1000 \mathrm{~m}^{3}\right)$.

communities are structured and how energy is transferred through the food web.

Longitude had the greatest variable importance ranking among all predictors, and this is likely because water masses and prey composition co-varied geographically along the NECC. The NECC is characterized by a shoaling thermocline and by increased productivity from west to east (Fiedler and Talley, 2006), and the classification tree allowed us to identify distinct regions along the NECC where myctophid diet was different. The zooplankton samples collected from the stations in each of the 3 geographic regions had different percentages of prey groups that contributed to myctophid diet patterns.

The offshore region was defined by a high abundance of pelagic ostracods in myctophid diets. This region was oceanographically distinct because of its mixed layer depth, low productivity, and high abundance of ostracods in contrast to the other regions. A deep MLD corresponds to reduced mixing, lower nutrient availability in surface waters, and oligotrophic conditions (Fiedler and Talley, 2006). Pelagic ostracods are typically most abundant in such oligotrophic conditions because of their greater ability to exploit environments low in food availability (Le Borgne and Rodier, 1997; Angel et al., 2007).

The nearshore region was defined by a high abun- dance of euphausiids in myctophid diets. This region was oceanographically distinct because of its shallow MLD and low saline waters. It typically displays elevated primary productivity and low oxygen levels (Fiedler and Talley, 2006). Extreme local rainfall and westward transport of water vapor across the Isthmus of Panama contribute to the low-salinity water mass in this location (Amador et al., 2006). Euphausiid abundance is typically greatest in productive, nearshore waters (Brinton, 1979; Simard et al., 1986), and that is the case here. Upwelling and biological production are greatest near the coast in the ETP, particularly the Gulf of Panama and the Costa Rica Dome than in other regions in the ETP (Lavín et al., 2006). Additionally, an oxygen minimum zone exists in the ETP; low oxygen values extend south into the Gulf of Panama (Fiedler and Talley, 2006). Some euphausiids, such as Euphausia diomedeae and E. mutica that were consumed by the myctophids in this study, are tolerant of low oxygen (Brinton, 1979).

Myctophids in the intermediate region had high numbers of copepods in their diets. This region, a transition zone between the nearshore and offshore, showed moderate mixed layer depths, salinities, and surface chlorophyll values in comparison with the higher and lower values of the other regions, respectively. Copepods were abundant throughout the study area but 


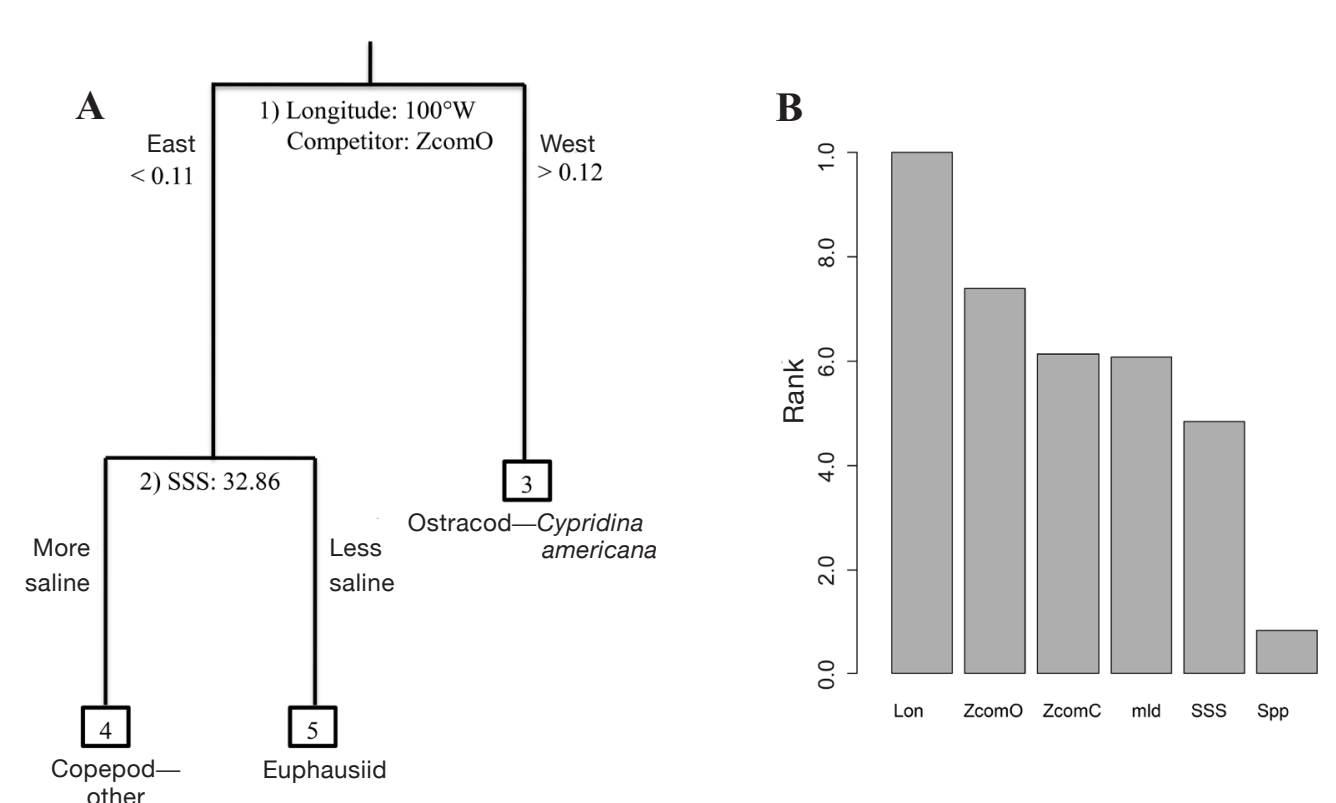

Figure 6

(A) The classification tree (at a $1 \mathrm{SE}$ resolution) used to predict myctophid (Myctophum nitidulum, Symbolophorus reversus, Gonichthys tenuiculus) diet composition from geographic, oceanographic, and biologic predictor variables (see Materials and methods section for further explanation). The prey group identified at each terminal node is that with the highest proportional numeric composition among all the prey in the myctophid samples that were mapped to each terminal node. (B) A variable importance plot showing rankings of each nonzero predictor variable used in the classification tree model. Lon=longitude; $\mathrm{ZcomO}=$ ostracod composition in the zooplankton net samples; ZcomC=copepod composition in the zooplankton net samples; mld=mixed layer depth; SSS=sea surface salinity; $\mathrm{Spp}=$ myctophid species

made up more than $80 \%$ of the community in the intermediate region, perhaps reflecting a competitive advantage that various copepods have in moderately oceanographic conditions (McGowan and Walker, 1985; Turner, 2004). In contrast, ostracods were limited in their range to oligotrophic conditions, and euphausiids were more dominant in productive nearshore environments (Brinton, 1979).

Previous research has indicated that $M$. nitidulum selects amphipods and ostracods and that $S$. reversus prey on euphausiids and amphipods (Van Noord et al. 2013b), and in fact dietary resource partitioning among myctophids has commonly been reported (e.g., Hopkins and Gartner 1992: Hopkins and Sutton 1998: Cherel et al., 2010), but the influence of oceanography on diet is less often considered. The selective feeding behavior observed by Van Noord et al, (2013b) is indicative of resource partitioning, but the current study expands on these initial findings and presents a more complete ecosystem-based analysis by including spatial, biological, and oceanographic variables in addition to dietary information. The current study indicates a very low level of resource partitioning among these species, as evidenced by the low importance of myctophid species in the ranking of variables. Indeed, when considering a fuller compliment of oceanographic, spatial, and prey composition data, we found that resource partitioning between species is not the most important aspect controlling diet. Therefore, dietary resource partitioning and competition among these species played minor roles in regulating feeding behavior, and spatial and oceanographic predictor variables outweighed resource partitioning. The importance of considering spatial, biological, and oceanographic variables when evaluating feeding behavior is clear, and the findings obtained from these variables have implications for interpreting previous results.

A diverse fish community structured through dietary resource partitioning can be affected by disturbance events and bottom-up forcing. For example, flying fish in the ETP consume many of the same prey that are consumed by myctophids, which could introduce a level of food competition (Van Noord et al., 2013a). During the course of our investigations, (August-November 2007), a tropical storm bisected the sampling area (15-17 October), resulting in enhanced upwelling, productivity, and zooplankton biomass in the wake of the storm. The flying fish community reflected these changes. Feeding success increased and diet composition changed in accordance with storm-induced chang- 

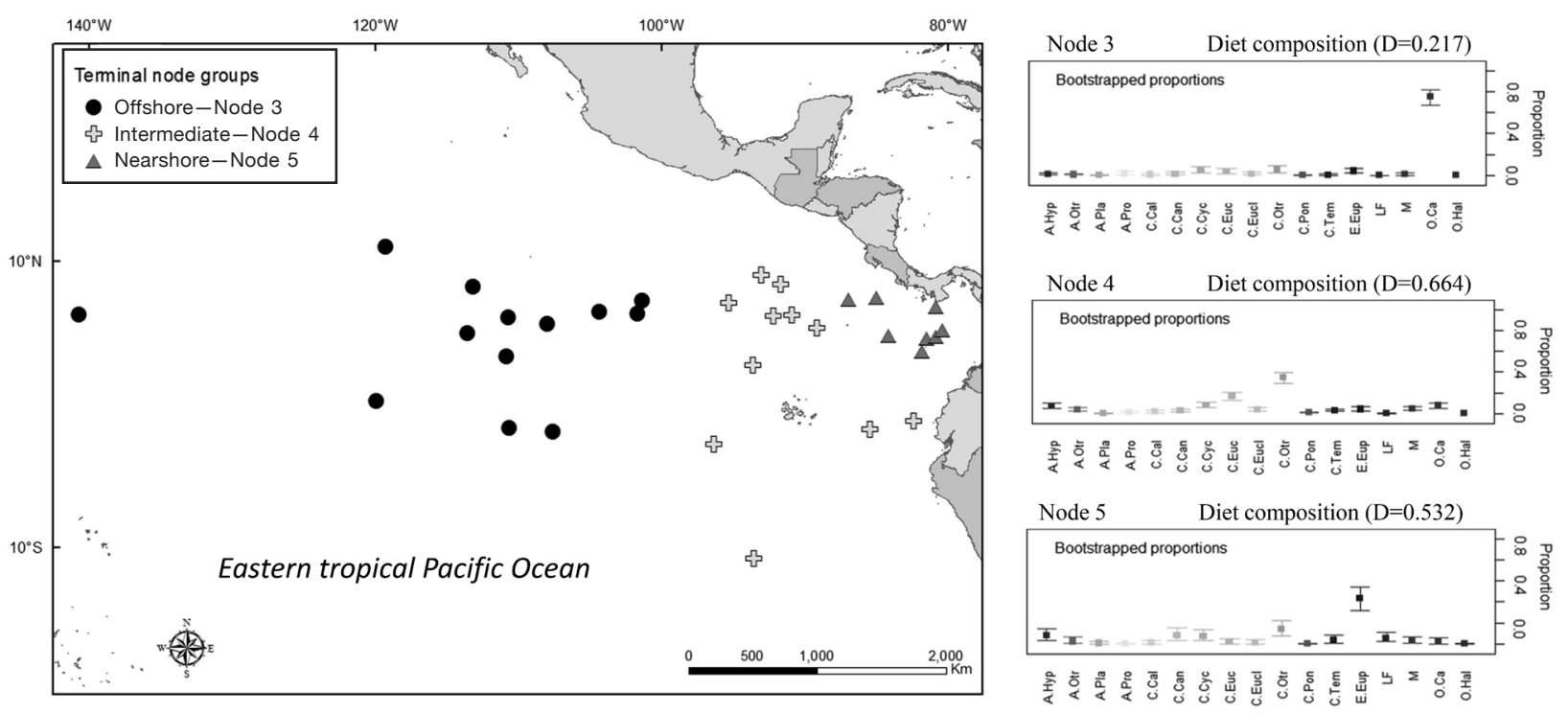

Figure 7

Map of terminal node groups 3, 4, and 5 in the classification tree of myctophid prey composition and showing the bootstrapped diet proportions for the myctophids grouped at each terminal node. Map displays symbols, which indicate the sampling stations where myctophids were feeding similarly according to the classification tree analysis. All stations occurred in waters $>3000 \mathrm{~m}$ and bathymetric contours (in $\mathrm{m}$ ) are displayed to show the depth ranges of our sampling. Diet diversity (D) values ranging from 0 (no diet diversity) to 1 (high diet diversity), are shown above each graph. Color gradients are provided for ease of viewing. Abbreviations are as follows: $\mathrm{A}=$ amphipod; $\mathrm{C}=$ copepod; $\mathrm{E}=\mathrm{euphausiid}$; A.Hyp=hyperiid amphipods; A.Otr=unidentifiable and rare amphipod types; A.Pla=platyscellid amphipods; A.Pro=pronoid amphipods; C.Cal=calanid copepods; C.Can=candaciid copepods; C.Cyc=cyclopoid copepods; C.Euc=euchaetid coepods; C.Eucl=eucalanid copepods;"C. Otr=unidentifiable and rare copepod types; C.Pon=pontellid copepods; C.Tem=temorid copepods; E.Eup=euphausiids,; $\mathrm{LF}=$ larval fishes; $\mathrm{M}=$ mollusks, O.Ca=Cypridina americana (ostracod); O.Hal=Halocyprida ostracods.

es in the prey community (Fiedler et al., 2013). These studies document the dynamic nature of the feeding habits of fish, and show that feeding patterns are not necessarily static; fish clearly respond to oceanographic conditions, in addition to displaying intrinsic behaviors that result in a more typical pattern of resource partitioning. This dynamic feeding behavior highlights the necessity of obtaining samples that adequately cover both temporal and spatial scales.

We sampled only surface migrating myctophids and therefore the interpretation of our data and implications for the broader myctophid community are limited. We did not include deeper dwelling individuals, and this limitation could alter both the feeding patterns observed and the size class of myctophids encountered. Sampling a broader spectrum of the myctophid population by using a suite of sampling gear that would cover the entire depth range for these fish could help to elucidate distributional patterns in the ETP and better address the role of resource partitioning in this fish community. As with all studies of fish feeding habits, taxonomic resolution of stomach contents impacts interpretation of the results. A finer taxonomic resolution may reveal a more subtle species-level diet partitioning among the myctophids. Prey size is also a function of the resolution of stomach samples and because we were unable to consistently quantify prey size in this study, it is possible that some species of myctophids partition diets on the basis of prey size rather than species, or some combination of size and species. As with most studies, a greater temporal sampling resolution would be beneficial for addressing longer term nuances in feeding ecology, and future work would benefit from seasonal and yearly sampling. Both these improvements are reinforced by the fact that our current analysis has shown the importance of physical variables in fish diet studies and highlights the need to include spatial, oceanographic and biological factors when evaluating feeding patterns of myctophids and of fish in general.

\section{Acknowledgments}

This research was partially funded by the University of San Diego and a Stephen Sullivan Memorial Scholarship. We thank the many scientists at the Southwest Fisheries Science Center, NOAA, who made these samples available, including: L. Ballance, P. Fiedler, V. Andreassi, C. Hall, M. Kelley, R. Pitman, and G. Wat- 
ters. We thank W. Watson for laboratory space and W. Walker for identifying the myctophid samples. We thank J. Barlow and P. Fiedler for use of smoothed oceanographic maps and 3 anonymous reviewers for their comments and editorial suggestions to improve this article at the manuscript stage.

\section{Literature cited}

Ahlstrom, E. H.

1971. Kinds and abundance of fish larvae in the eastern tropical Pacific, based on collections made on EASTROPAC I. Fish. Bull. 69:3-77.

1972. Kinds and abundance of fish larvae in the eastern tropical Pacific on the second multivessel EASTROPAC survey, and observations on the annual cycle of larval abundance. Fish. Bull. 70:1153-1242.

Amador, J. A., E. J. Alfaro, O. G. Lizano and V. O. Magaña. 2006. Atmospheric forcing of the eastern tropical Pacific: a review. Prog. Oceanogr. 69:101-142. Article

Angel, M. V., K. Blachowiak-Samolyk, I. Drapun, and R. Castillo, $\mathrm{R}$.

2007. Changes in the composition of planktonic ostracod populations across a range of latitudes in the North-east Atlantic. Prog. Oceanogr. 73:60-78. Article

Barlow, J., M. C. Ferguson, E. A. Becker, J. V. Redfern, K. A. Forney, I. L. Vilchis, P. C. Fiedler, T. Gerrodette, and L. T. Ballance.

2009. Predictive modeling of cetacean densities in the Eastern Pacific Ocean. NOAA Tech. Memo. NMFSSWFSC-444, 206 p.

Breiman, L., J. H. Friedman, R. A. Olshen, and C. J. Stoned. 1984. Classification and regression trees, 358 p. Chapman and Hall, Boca Raton, FL.

Brinton, E.

1979. Parameters relating to the distributions of planktonic organisms, especially euphausiids in the eastern tropical Pacific. Prog. Oceanogr. 8:125-189. Article

Brodeur, R., S. McKinnell, K. Nagasawa, W. Pearcy, V. Radchenko, and S. Takagi.

1999. Epipelagic nekton of the North Pacific Subarctic and Transition Zones. Prog. Oceanogr. 43:365-397. Article

Catul, V., M. Gauns, M., and P. K. Karuppasamy.

2011. A review on mesopelagic fishes belonging to family Myctophidae. Rev. Fish Biol. Fish. 21:339-354. Article

Cherel, Y., C. Fontaine, P. Richard, and J.-P. Labat.

2010. Isotopic niches and trophic levels of myctophid fishes and their predators in the Southern Ocean. Limnol. Oceanogr. 55:324-332. Article

Chipps, S. R., and J. E. Garvey.

2007. Assessment of diets and feeding patterns. In Analysis and interpretation of freshwater fisheries data (C. S. Guy and M. L. Brown, eds.), 473-514. Am. Fish. Soc., Bethesda, MD.

Clarke, T. A.

1980. Diets of fourteen species of vertically migrating mesopelagic fishes in Hawaiian waters. Fish. Bull. 78:619-640.

Coad, B. W.

1998. Expedition field techniques: fishes, $2^{\text {nd }}$ ed., $97 \mathrm{p}$. Geography Outdoors, Royal Geographical Society, London.
Collins, M. A., J. C. Xavier, N. M. Johnston, A. W. North, P. Enderlein, G. A. Tarling, C. M. Waluda, E. J. Hawker, and N. J. Cunningham.

2008. Patterns in the distribution of myctophid fish in the northern Scotia Sea ecosystem. Polar Biol. 31:837-851. Article

Davison, P. C., D. M. Checkley Jr., J. A. Koslow, and J. Barlow. 2013. Carbon export mediated by mesopelagic fishes in the northeast Pacific Ocean. Prog. Oceanogr. 116:14-30. Article

Fernández-Álamo, M. A., and J. Färber-Lorda.

2006. Zooplankton and the oceanography of the eastern tropical Pacific: a review. Prog. Oceanogr. 69:318-359. Article

Fiedler, P. C., and L. D. Talley.

2006. Hydrography of the eastern tropical Pacific: a review. Prog. Oceanogr. 69:143-180. Article

Fiedler, P., J. V. Redfern, J. Van Noord, C. Hall, R. L. Pitman, and L. T. Ballance.

2013. Effects of a tropical cyclone on a pelagic ecosystem from the physical environment to top predators. Mar. Ecol. Prog. Ser. 484:1-16. Article

Gago, F. J., and R. C. Ricord.

2005. Symbolophorus reversus: a new species of lanternfish from the eastern Pacific (Myctophiformes: Myctophidae). Copeia 2005:138-145.

Gjosaeter, J., and K. Kawaguchi.

1980. A review of the world resources of mesopelagic fish. FAO Fish. Tech. Pap. 193, 151 p. FAO, Rome.

Hopkins, T. L., and J. V. Gartner Jr.

1992. Resource-partitioning and predation impact of a low-latitude myctophid community. Mar. Biol. 114:185-197. Article

Hopkins, T. L., and T. T. Sutton.

1998. Midwater fishes and shrimps as competitors and resource partitioning in low latitude oligotrophic ecosystems. Mar. Ecol. Prog. Ser. 164:37-45. Article

Irigoien, X., T. A. Klevjer, A. Røstad, U. Martinez, G. Boyra, J. L. Acuña, A. Bode, F. Echevarria, J. I. Gonzalez-Gordillo, S. Hernandez-Leon, S. Agusti, D. L. Aksnes, C. M. Duarte, and S. Kaartvedt.

2014. Large mesopelagic fishes biomass and trophic efficiency in the open ocean. Nat. Commun. 5:3271. Article

Kinzer, J., and K. Schulz.

1985. Vertical distribution and feeding patterns of midwater fish in the central equatorial Atlantic. Mar. Biol. 85:313-322. Article

Kuhnert, P. M., L. M. Duffy, J. W. Young, and R. J. Olson.

2012. Predicting fish diet composition using a bagged classification tree approach: a case study using yellowfin tuna (Thunnus albacares). Mar. Biol. 159:87-100. Article

Lavin, M. F., P. C. Fiedler, J. A. Amador, L. T. Ballance, J. Färber-Lorda, and A. M. Mestas-Nuñez.

2006. A review of eastern tropical Pacific oceanography: summary. Prog. Oceanogr. 69:391-398. Article

Le Borgne, R., and M. Rodier.

1997. Net zooplankton and the biological pump: a comparison between the oligotrophic and mesotrophic equatorial Pacific. Deep Sea Res. (II Top. Stud. Oceanogr.) 44:2003-2023. Article

Longhurst, A. R., and W. G. Harrison.

1988. Vertical nitrogen flux from the oceanic photic zone by diel migrating zooplankton and nekton. Deep-Sea Res., A. 35:881-889. Article 
Maas, A. E., S. L. Frazar, D. M. Outram, B. A. Seibel, and K. F. Wishner.

2014. Fine-scale vertical distribution of macroplankton and micronekton in the Eastern Tropical North Pacific in association with an oxygen minimum zone. J. Plankton Res. 36:1557-1575. Article

McGowan, J. A., and P. W. Walker.

1985. Dominance and diversity maintenance in an oceanic ecosystem. Ecol. Monogr. 55:103-118.

Moteki, M., M. Arai, K. Tsuchiya, and H. Okamoto.

2001. Composition of piscine prey in the diet of large pelagic fish in the eastern tropical Pacific Ocean. Fish. Sci. 67:1063-1074. Article

Naito, Y., D. P. Costa, T. Adachi, P. W. Robinson, M. Fowler, and A. Takahashi.

2013. Unravelling the mysteries of a mesopelagic diet: a large apex predator specializes on small prey. Funct. Ecol. 27:710-717. Article

Ohman, M. D., and P. E. Smith.

1995. A comparison of zooplankton sampling methods in the CalCOFI time series. CalCOFI Rep. 36:153-158.

Olson, R. J., L. M. Duffy, P. M. Kuhnert, F. Galván-Magaña, N. Bocanegra-Castillo, V. Alatorre-Ramírez.

2014. Decadal diet shift in yellowfin tuna Thunnus albacares suggests broad-scale food web changes in the eastern tropical Pacific Ocean. Mar. Ecol. Prog. Ser. 497:157-178. Article

Pakhomov, E. A., R. Perissinotto, and C. D. McQuaid.

1996. Prey composition and daily rations of myctophid fishes in the Southern Ocean. Mar. Ecol. Prog. Ser. 134:1-14. Article

Pepin, P.

2013. Distribution and feeding of Benthosema glaciale in the western Labrador Sea: fish-zooplankton interaction and the consequence to calanoid copepod populations. Deep Sea Res. (I Oceanogr. Res. Pap.) 75:119-134. Article

Perrin, W. F., R. R. Warner, C. H. Fiscus, and D. B. Holts.

1973. Stomach contents of porpoise, Stenella spp., and yellowfin tuna, Thunnus albacares, in mixed-species aggregations. Fish. Bull. 71:1077-1092.

Pusch, C., S. Schnack-Schiel, E. Mizdalski, and H. von Westernhagen.

2004. Feeding ecology of three myctophid species at the Great Meteor Seamount (North-east Atlantic). Arch. Fish. Mar. Res. 51:251-271.

$\mathrm{R}$ Core Team.

2014. R: a language and environment for statistical computing. R Foundation for Statistical Computing, Vienna, Austria. [Available at website. org, accessed July 2014.]

Rissik, D., and I. M. Suthers.

2000. Enhanced feeding by pelagic juvenile myctophid fishes within a region of island-induced flow disturbance in the Coral Sea. Mar. Ecol. Prog. Ser. 203:263-273. Article

Saunders, R., M. A. Collins, P. Ward, G. Stowasser, R. Shreeve, and G. A. Tarling.

2015. Distribution, population structure and trophodynamics of Southern Ocean Gymnoscopelus (Myctophidae) in the Scotia Sea. Polar Biol. 38:287-308. Article

Schoener, T. W.

1974. The compression hypothesis and temporal resource partitioning. Proc. Natl. Acad. Sci. 71:4169-4172.
Scott, M. D., S. J. Chivers, R. J. Olson, P. C. Fiedler, and K. Holland.

2012. Pelagic predator associations: tuna and dolphins in the eastern tropical Pacific Ocean. Mar. Ecol. Prog. Ser. 458:283-302. Article

Shchetinnikov, A. S.

1992. Feeding spectrum of squid Sthenoteuthis oulaniensis (Oegopsida) in the eastern Pacific. J. Mar. Biol. Ass. U. K. 72:849-860. Article

Shreeve, R. S., M. A. Collins, G. A. Tarling, C. E. Main, P. Ward, and N. M. Johnston.

2009. Feeding ecology of myctophid fishes in the northern Scotia Sea. Mar. Ecol. Prog. Ser. 386:221-236. Article

Simard, Y., R. de Ladurantaye, and J. C. Therriault.

1986. Aggregation of euphausiids along a coastal shelf in an upwelling environment. Mar. Ecol. Prog. Ser. 32:203-215.

Smith, P. E., and S. L. Richardson.

1977. Standard techniques for pelagic fish egg and larva surveys. FAO Fish. Tech. Pap. 175, 108 p.

Spear, L. B., D. G. Ainley, and W. A. Walker.

2007. Foraging dynamics of seabirds in the eastern tropical Pacific Ocean. Stud. Avian Biol. 35:1-99.

Suntsov, A. V., and R. D. Brodeur.

2008. Trophic ecology of three dominant myctophid species in the northern California Current region. Mar. Ecol. Prog. Ser. 373:81-96. Article

Therneau, T., B. Atkinson, and B. Ripley.

2013. rpart: recursive partitioning and regression trees. $\mathrm{R}$ package vers. 4.1-3. [Available at website, accessed October 2013.]

Turner, J. T.

2004. The importance of small planktonic copepods and their roles in pelagic marine food webs. Zool. Stud. 43:255-266.

Tyler, H. R., Jr., and W. G. Pearcy.

1975. The feeding habits of three species of lanternfishes (family myctophidae) off oregon, USA. Mar. Biol. 32:7-11. Article

Van Noord, J. E.

2013. Diet of five species of the family Myctophidae caught off the Mariana Islands. Ichthyol. Res. 60:89-92. Article

Van Noord, J. E., E. A. Lewallen, and R. L. Pitman.

2013a. Flyingfish feeding ecology in the eastern Pacific: prey partitioning within a speciose epipelagic community. J. Fish Biol. 83:326-342. Article

Van Noord, J. E., R. J. Olson, J. V. Redfern, and R. S. Kaufmann. $2013 \mathrm{~b}$. Diet and prey selectivity in three surface-migrating myctophids in the eastern tropical Pacific. Ichthyol. Res. 60:287-290. Article

Watanabe, H., K. Kawaguchi, and A. Hayashi.

2002. Feeding habits of juvenile surface-migratory myctophid fishes (family Myctophidae) in the Kuroshio region of the western North Pacific. Mar. Ecol. Prog. Ser. 236:263-272. Article

Watanabe, H., M. Moku, K. Kawaguchi, K. Ishimaru, and A. Ohno.

1999. Diel vertical migration of myctophid fishes (Family Myctophidae) in the transitional waters of the western North Pacific. Fish. Oceanogr. 8:115-127. Article

Wisner, R. L.

1974. The taxonomy and distribution of lanternfishes (family Myctophidae) of the eastern Pacific ocean. Navy Ocean Research and Development Activity (NORDA), Rep. 3, 229 p. U.S. Govt. Print. Off., Washington, D.C. 